\title{
Kazakh Academy of Sciences in trouble with Moscow
}

\section{London}

THE Academy of Sciences of the Kazakh SSR has failed to carry out tasks vital to the Soviet economy, according to a representative of the Central Committee of the Communist Party of the Soviet Union. Mikhail Solomentsev, chairman of the Party Control Committee of the Central Committee, visited the Kazakh capital, Alma-Ata, in the wake of the student demonstrations of 17-18 December, and castigated the Kazakh academicians on several scores. They had, he claimed, failed to resolve vital problems of the integration of science and production in due time; there had been "false accounting" and "infringement of the principles of selection and education of cadres", and there had been a lack of the glasnost' (openness) that is the official keynote of the Gorbachev regime. The academy, Solomentsev concluded, exibits a "substantial alienation" from the task of Kazakhstan's "socio-economic development".

Clearly the unrest had a significant nationalist content. The protests were sparked by the replacement of the retiring Kazakh First Secretary of the Communist Party of Kazakhstan by a Russian, but this in itself would probably not have been a sufficient cause. (As a Hungarian newspaper pointed out, the First Secretary of Kazakhstan in 1955-56 was Leonid Brezhnev, and he encountered no nationalist upheavals.) But during the past few years, there has been growing concern among the traditionally Muslim peoples of Soviet Central Asia that their interests have been subordinated to those of Russia proper and the Western republics of the USSR. To accuse the Kazakh scientists of neglecting the interests of their republic is thus to throw doubt on all Kazakh national aspirations. Solomentsev's allegation that the academy had given less help than it is capable of in drafting environmental conservation measures must have been particularly stinging.

The students directly involved in the demonstrations have come in for heavy criticism in the media, particularly at the All-Union level. Sotsialisticheskaya Industriya claimed that some of them were "stimulated" by drugs. The young Communists' paper Komomolskaya Pravda criticized the facts that the "overwhelming majority" of students in Kazakhstan were Kazakhs "although people of over 100 nations and nationalities live in the republic", that they were housed in hostels according to nationality, and that the majority of trouble-makers came from the ethnically homogeneous southern regions of the republic, had attended schools where Kazakh was the language of instruction and had only a poor knowledge of Russian.

Accordingly, top party officials (including the military commander of Soviet Central Asia) have been sent to the various universities and higher education institutions to address the students and staff on their socialist obligations, and a meeting was held last week between the new First Secretary of Kazakhstan, Gennadii Kolbin, and university and college rectors Kolbin stressed a number of negative factors in the university admission procedures, "gross miscalculations" in the orga- nization of education and training, and a "mistaken" cadre policy which had a negative effect on the students' weltanschauung, which was, he alleged a contributory factor to the past months' "hooliganism". Meanwhile, urgent measures have been rushed through the Kazakh Council of Ministers to release funds for the construction of new student hostels by mothballing laboratory, computer and university administrative blocks already under construction.

Vera Rich

- Other practical steps have been taken. The Young Communists', secretary for the first-year physics courses at the Kazakh State University has recently received a seven-year sentence for "inciting" the December disturbances, and a student is now facing trial for perjury in connection with the case.

\section{US-Japanese research initiative renegotiates cooperative projects}

\section{Washington}

A HIGH-LEVEL delegation, led by White House Science Advisor William Graham, will travel to Tokyo next week to prepare for renewing an agreement with Japan, due to expire at the end of April, for the promotion of cooperative research and development in science and technology. One aim of the visit is to discuss what the United States considers to be imbalances in the treaty; at least one member of the delegation believes those imbalances need serious attention.

Frances $\mathrm{Li}$, a senior policy analyst for the White House Office of Science and Technology Policy, says the United States would like to see a presidential agreement such as that for science and technology focusing on a few high-profile projects. Although she will not speculate on what those projects might be, she feels they must be of sufficient stature and importance to warrant the attention the bilateral agreement is receiving. The US delegation will also seek to spell out more thoroughly the basis for joint cooperation at all levels of research.

Government agencies included in the initial agreement, which was signed in 1979, have had mixed experience of the cooperative projects. At the National Aeronautics and Space Administration and the Department of Health and Human Services, joint programmes started immediately, and some flourished. But at the Environmental Protection Agency (EPA), none of the projects initially proposed got off the ground. Although EPA has 14 joint exchanges with Japan for sharing environmental information, none of these involves research cooperation and they are covered by a separate agreement. John Moore, the National Science Foundation's deputy director, will be a member of the US delegation, together with assistant secretary John Negroponte from the State Department and assistant secretary Bruce Merrifield from the Commerce Department. Merrifield is one of those who believes that information has been flowing one way from the United States to Japan. He says that semantic difficulties have sometimes clouded issues of what is permitted under the agreement. But, says Merrifield, "in many cases, the Japanese have clearly understood what they're doing and have taken advantage of us." By erecting barriers to innovation, such as inappropriate government regulation and antiquated anti-trust laws, US research has been an easy target for exploitation, according to Merrifield.

Merrifield believes that the new Federal Technology Transfer Act signed into law last year (see Nature 323, 659; 1986) will change things. The law is designed to encourage federally supported research laboratories to seek commercial partners for in-house research. Merrifield believes this will cause the supply of 'free' information to dry up, which is why, he says, Japan is "desperately anxious to have this [agreement] renegotiated". But he insists that will not happen unless the Japanese come closer to a more equitable sharing of resources and talent.

Japan appears sensitive to Western concern about cooperative research. One Japanese initiative, the Human Frontiers Science Program, would promote 'internationalization' of scientific research. Projected to cost 1 million million yen over its 20-year life, Japan has proposed a 200 million yen starting budget for 1987 . But the Human Frontiers Science Program is more of a multinational effort, and may not be part of the bilateral discussions next week. 